\title{
Access, Understanding, and Religion Media Creation of Students at Pesantren Based Madrasah Aliyah (MA) in Magelang Regency
}

\author{
Umi Masfiah ${ }^{1}$, Nugroho Eko Atmanto ${ }^{2}$ \\ \{masfiah.umi@gmail.com ${ }^{1}$, nugroho.blas@gmail.com ${ }^{2}$ \} \\ Religious Research and Development Ministry of Religious Affairs Semarang Indonesia, \\ $+6281575235676^{1},+6285866275800^{2}$
}

\begin{abstract}
This study focus in Madrasah Aliyah YAJRI (MA YAJRI) Magelang. This madrasah has a policy a prioritizing the study of the kitab kuning, and providing students to access the internet with limited access. Nevertheless, the results of the study indicated that KSM members in accessing the most often read the Al-Qur'an with a score of 3.8 (very often), reading religious books other than books of PAI (Pendidikan Agama Islam) and reading kitab kuning with a score of 3.4 (very often) and reading newspapers with a score of 3.2 (very often). The last order of media that read by KSM members was reading magazines with a score of 2.9 (often). The comprehension of student member of KSM on religious books, book material, and Kitab Imriti was categorized into very well. The students can make a bulletin "Sirajuna" and the publication of the "Buku Ontologi Puisi" and the "Buku Ontologi Cerpen”.
\end{abstract}

Keywords: Access, comprehension, media creation, pesantren, Madrasah Aliyah YAJRI Magelang,

\section{Introduction}

Based on the institutional system, pesantren based madrasah aliyah (islamic senior high school) (islamic boarding school) is linked to under the pesantren, so that policies for the development of madrasah aliyah refer to the policies of pesantren. Pesantren has a characteristic that still exists nowadays, namely the study of the kitab kuning (Arabic Classic Book) [1]. The study of the kitab kuning is the main source of religious knowledge in psesantren, so that students (including students at pesantren based madrasah aliyah are demanded to master the kitab kuning by reading and understanding the contents of the book. The competence of mastering the kitab kuning does not require internet media access facilities due to the learning procedure is through the sorogan and bandongan method or face to face with kiai. Thus, when referring to these competencies, internet media is not really needed. In addition, the concern that internet access will consume students' time, neglect religious learning in the form of the kitab kuning study, and will only be used as a means of socializing with the opposite sex, it becomes a consideration in which it cannot be ignored by management and other elements of the pesantren.

On the other hand, internet access is one of the necessities to support the competence of other general subjects such as Indonesian, and other subject matter. Internet access is also needed to support the competence of students in facing the information and technology 
developments in the current era of globalization. Hence, along with the times, internet media access at Madrasah Aliyah YAJRI (MA Yajri) Magelang is opened with a policy of very limited restrictions. Students, as well as students from the Pesantren of Siradjul Mukhlasin 2 are prohibited to bring cellphone and laptop, to read literary books in the form of romance novels, and it can only access internet media when participating in the extra-curricular activities of the Komunitas Santri Menulis / KSM (Student Community for Writing. The policy of Pesantren, on the one side, it can strengthen the students to concentrate more on studying religious knowledge, and on the other hand, it provides facilities to achieve the competence of students towards other general subject matter that requires internet media access methods.

Several studies on literacy in islamic senior high school have 3 tendencies, namely: first, the study of the literacy movement in Islamic boarding schools, Arifina [2], Ja'far [3], Ghazali and Herman [4], Maskur [5], muchibin and Latifah [6], Muhith [7], Fitriyah, Marlina and Suryani [8], Anwar, Komariah and Rohman [9], Hasanah [10], Mukaromah, Selli Annafi'atul \& Anwar [11], Ihsan [12], Rifauddin, Ariyanti and Pratama [13], Setiawan [14]. Second, the study on the portrait of literacy practice in islamic senior high school Maknun [15], Muslim [16], Iswanto [17], Nur [18], Azani [19]. Third, the use of literacy to improve character formation Asma'ruf Priyatama [20], Citra Ningrum, 2aharudin [21], Setyaningsih et al [22]

The study about the access, comprehension and creation of religious media at MA YAJRI Magelang is actually a study to enrich studies on media literacy in pondok pesantren-based islamic madrasah aliyah that has been undertaken previously. This study provides an overview of access to religious information, comprehension and creation of religious information through the extra-curricular activities of the Komunitas Santri Menulis KSM . KSM is considered to be an alternative middle way from pondok pesantren-based islamic madrasah aliyah which on the one side wants to maintain the concept of the kitab kuning study and on the other hand, adapting to developments in knowledge and technology. KSM is the embodiment of the concept of limited internet media access and is considered a positive internet access for students of MA YAJRI students, as well as students from Pesantren of Sirajul Mukhlasin II.

Positive internet access is applied with a program of planned, limited internet access, and supervision from the teacher so that it can encourage the students have wise behavior in accessing, understanding and creating media through useful writing. To discover the media literacy skills, there are 3 forms of activities carried out, namely access, comprehension, and media creation. Accessing in media literacy activities consists of 4 components, namely: (1) determining and articulating the nature, the role and scope of information and media (content) through various resources, (2) searching and finding information and media content, (3) accessing needed information and media content effectively, efficiently and ethically as well as media and information providers, and (4) retrieving and embracing temporarily information and media content using various methods and tools [23].

Comprehension is expressed by evaluation, that consists of 4 components, namely: (1) understanding the needs of media and information providers in society, (2) assessing, analyzing, comparing, articulating and applying initial criteria for assessing information taken and its sources, and evaluating media and providers. information in the society, (3) evaluating and validating the information and media content collected and its sources and media providers and information in the society, (4) synthesizing and organizing the information and media content collected [23].

Creation consists of 4 components, namely: (1) compiling and producing new information, media content or knowledge for a specific goal in an innovative, ethical and creative way, (2) communicating information, media content and knowledge ethically, legal and effective use of appropriate channels and tools, (3) engaging with media and information providers for self- 
expression, intercultural dialogue and democratic participation through various means in an ethical, effective and efficient manner, (4) monitoring the impact of information generated and distributed, media content and knowledge as well as using existing media and other information providers [24].

The three processes above, it becomes the reference to practice in accessing religious media at MA YAJRI Magelang. Access, comprehension (in the form of students' understanding of the media), and media creation through KSM activities are significant to be studied to find out how the religious media literacy strategy carried out by MA YAJRI as one of the pesantren-based madrasah aliyah.

\section{Metode}

This study was a mix method, the qualitative aspect was carried out through interviews, document study, observation, and FGD. The quantitative aspect was carried out to discover the attitudes and comprehension of KSM member students. Interview activities were addressed to the Caregivers of Pesantren Siradjudin II. The Principal of MA YAJRI, KSM teachers, KSM member students, non KSM members, the Head of the Library, and the Head of Administration.

To find out the attitude of KSM member students regarding to aspects of access, comprehension, media creation, thus, it was carried out by giving a questionnaire related to these three aspects. The questionnaire of access aspect was to discover the level of student access to various printed media (Alquran, the kitab kuning, newspapers, magazines, religious books), electronic media (television), the internet (youtube, articles, lectures, facebook, blogs), and to find out students' attitudes about the urgency of internet accessibility for students. The questionnaire of comprehension aspect was used to explore how much students' understanding on the religious books, kitab kuning, discourse of kiai/ustadz). The media creation aspect questionnaire was used to explore the potential of the work of KSM member students in writing papers on various media.

\section{Finding and discussion}

\subsection{The overview of Madrasah Aliyah (MA) YAJRI Payaman, Magelang}

MA Yajri is islamic senior high school that has been established for quite a long time, in 1976, it was founded by pesantren Foundation of Sirojul Mukhlasin II, it is located at Jalan Kalibening No. 64, Payaman Village, Secang District, Magelang Regency, Central Java 56195. As the madrasah aliyah that integrated with pesantren, in the 2018/2019 academic year, it had 506 students, with 40 teachers.

As one of the programs for literacy development, thus, MA Yajri is equipped with infrastructure. The foundation provides, among others: library, electronic media (television), Laboratory of IT contains 59 units of internet-connected computers. Students can use the available facilities according to the existing schedule. Besides, teachers are also facilitated to attend IT training by bringing the instructors or sending training participants (Gunaryo, head of administration, interview, 2 October 2018).

\subsection{Type of media and access time of media}


To associate with the fulfillment of various media, the types of media used by students to gain an information at MA YAJRI, it covers print media, electronic media and online media. Print media consists of books in the collection of MA YAJRI's library, besides, the compulsory subject matter books are available, Alquran, kitab kuning, newspapers, magazines also found in the library. Meanwhile, the type of electronic media is only television. The online media used to access information by students at MA YAJRI, it includes of You Tube, blogs, and WA. Electronic and online media can be accessed only on holidays, days out, parent's visit time, and extra activities of KMS. Even so, two matters that were prohibited in accessing the media, namely students were not allowed to read novels about romance and were not allowed to use social media for dating (Ustadz Ade, interview, 2 October 2018).

The policy of Pesantren Sirajul Mukhlasin has an open view toward technology as an element of human life that must be accepted. However, the pesantren provides restrictions on internet access, as an educational strategy, with the intention of providing control, firstly in order to students can avoid accessing negative information and content, or use the internet for things that are not useful, for example chatting with other internet users, secondly to limit students so that they are not trapped or become complacent about wasting time and energy on the internet, whereas, the focus of pesantren is learning from the book and kiai / ustadz / teachers. Considering to this reason, a schedule for the use of the internet had been designed for students and a prohibition on carrying cellphones in pesantren / islamic madrasah aliyah (Kiai Minanurrahman, interview, 2 October 2018). The Head of the Supreme Court also agreed with the regulations on restrictions on media access, including prohibiting the use of cellphones in the islamic madrasah aliyah / pesantren environment, with the intention was that students concentrated more in learning activities (Masykur, interview, 2 October 2020).

The effort to introduce internet media so that students can become literate with technology, it has been undertaken through the effort to establish an internet cafe at the pesantren however this has not received permission from the boarding school management. The idea of the KSM advisor by opening an internet cafe can control the activities of students when accessing the internet on Friday holidays.

\subsection{The Support of pesantren management toward religious media access through the internet}

Ustadz Ade, KSM advisor (Interview 4 October 2018) asserted that through there were opportunities to develop children's potential through KSM, for example videography training, digital literacy development, reading poetry, and others. Through internet access, students can also add to their religious insights that were not achieved by only learning from print media.

The support on the existence of the (KSM) is a middle way for the students because of the prohibition on bringing the cellphones and laptops. The availability of 52 computers is very useful to support this activity. The teachers in Madrasah aliyah for the use of internet media are supportive. According to him; by using internet media, students are more likely to read and write.

In general, the view of pesantren managements, the principle of madrasah aliyah and teachers on internet access programs for students, they support internet-based religious media literacy activities. Teachers of religious groups (Islamic Cultural History, Islamic Jurisprudence, Akidah / morals, Alquran / Hadith, Fatkhul Qarib) stated that they needed internet facilities for learning activities. Meanwhile, only the nahwu teacher said that they did not need the internet because students learned and memorized through books / books (FGD, 
October 2, 2018).

However, there are also obstacles faced by madrasas, due to limited facilities that cause to take turns to access and time constraints, so that they cannot be free to create more optimally. Madrasah aliyah teachers are also worried about negative, provocative content and the use of the internet for entertainment, thus, the guidance and supervision are needed.

The pesantren are still an alternative to provide internet access opportunities through KSM extra-curricular activities, which are held from 14.00 to 15.00 . The membership of KSM comes from students from the MTs level to students from Madrasah aliyah, both male and female.

Meanwhile, students who do not KSM members, they have the opportunity to access the internet only on their "day out". The opportunity, which is only scheduled once every 2 months apart from shopping for various needs or eating out, it is also utilized to access the internet by opening Facebook, Twitter, You Tube and other links through public facilities (interview with students, 11 October 2018)

Students of MA YAJRI as well as students of Pesantren Sirojul Mukhlasin II Payaman can also access internet media by utilizing the "The Schedule of Parents Visit", which is once every 35 days. On this occasion, students can spend a day with their parents while opening their cellphones to view Facebook, You Tube and others. A student said that another opportunity was during holidays, to be able to access the internet by opening Facebook, Twitter and others to connect with distant friends (interview with students, 5 October 2018)

\subsection{Student community for writing at Madrasah Aliyah (MA) YAJRI Magelang}

The Student Community for Writing (KSM) activity is held every Tuesday (for male students) and Thursday (for female students) at 14.00 WIB - 15.00 WIB. KSM members consist of 30 male participants and 16 female participants.

The formation of KSM was led by Ade Listyanto, Indonesian Language Teacher as well as KSM coach, and assisted by Ulil, Fatkhul Qarib Book Subject Matter Teacher. The motivation for KSM coaches to open extra-curricular media literacy activities was that students must be technologically literate (Ustaz Ade, interview, October 2, 2018). The formation of KSM began when students were given assignments to write short stories in 2017. In fact, the tasks responded quite enthusiastically by students because almost one hundred were collected. short story works. Dealing with the reason, there were ideas to create a forum for students who had the potential to write, namely by making KSM activities, both from Madrasah Tsanawiyah / MTs (Islamic Yunior High School) and MA students. The plan received support from the Head of MTs and MA and then the Students Community for Writing was formed since November 11, 2017 (Listiyanto interview, October 4, 2018).

The existence of KSM is very meaningful, the existing 52 units of computer facilities can be more useful, which previously were only used during the implementation of the Ujian Nasional (National Examination). Through KSM, it also allows students to practice being creative or expressing ideas through computers

The real work of KSM activities is written work in the form of the Sirajuna Bulletin, which is published once a month. In each KSM activity, the head of the bulletin determines the theme, writing, distribution of writing and others, while the KSM supervisor only directs and makes revisions if it is necessary. The division of tasks was carried out in order to KSM members will be able to be independent and since the beginning, the KSM coach had confirmed that; "Don't let the power depending on the teacher but the children" (Listiyanto, interview, 4 October 2018).

The submission of full responsibility to KSM members to compile bulletin is to establish the independence of students in managing KSM extra-curricular activities. The KSM coach 
expects that although the coaches of KSM cannot guide all the time, the community can survive. Ustadz Ade implemented a system of managing extra-curricular activities independently because his experience who ever coached a writing community in previous years was not successful. The community only produced 2 editions of the newsletter publication after that it disbanded because it only relied on the guidance of the community coach (interview with ustadz Ade, 4 October 2018).

Apart from compiling the Sirajuna Bulletin, other KSM support activities are the publication of the Poetry Ontology Book and the Short Story Ontology Book. For October 2018, there were additional activities to access the display of students drama on You Tube. This activity was carried out by a team that will fill in the activities of the Santri Day, October 22, 2018. To prepare for the appearance of the students' drama, several KSM members prepared themselves by accessing the display of the students' drama on You Tube as a reference for the drama series that they will show (Observation of activities KSM, October 4, 2018)

Although KSM had been made as the official extra-curricular activity of MA YAJRI, the activity program that had not been arranged specifically. Usually, the individual who designed KSM activities was the Head of KSM. Every time the activity will be started, the Head of KSM will report to the advisor about what things will be accessed by KSM participants (interview with students, October 4, 2018). In each KSM activity implementation, the Head of KSM had coordinated the duties of each member which will be carried out during the KSM activity. KSM members were in charge of writing short stories, poetry, articles, news and others. So that when the activity took place, they did their job according to the job that had been assigned. KSM advisors merely supervised, when, there were students who had difficulty accessing computers, usually they will ask for help from the advisor (Observation of KSM activities, 4 October 2018).

In addition to technical guidance in accessing computers, KSM supervisors also introduceed the procedures for accessing online media (internet) so that they were always careful in accessing the media. If SPAM appeared, don't click it and some recommended links to access include of detik.com, islam.com. (interview with Ade Listiyanto, 4 October 2018).

\subsection{Access, comprehension and media creation of KSM Members at MA YAJRI Magelang}

After about 1 year of participating in the KSM activity, students are required to their opinion about the benefits of participating in the KSM activity. The answers of MA YAJRI students who are members of KSM can be seen in the following graph. 


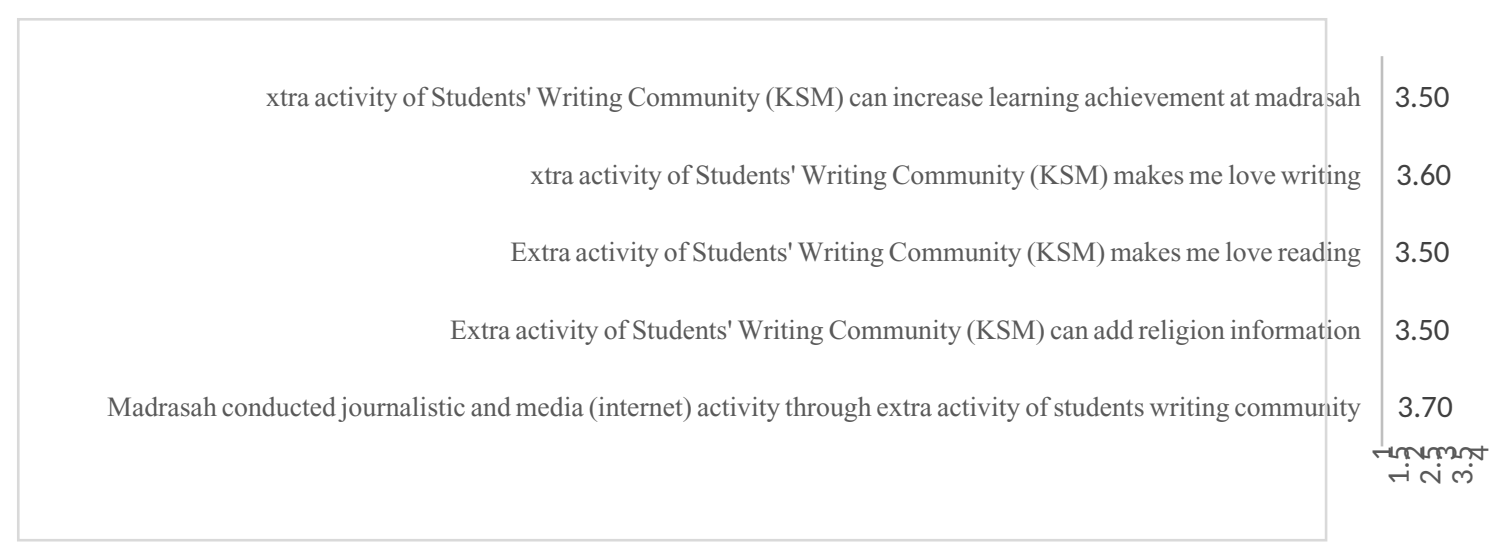

Fig. 1. Benefits of Participating in KSM Activities

The fig. above points out that students strongly agree with the extra-curricular activities with a score of 3.7 (Strongly agree). They argue that participating in KSM activities can provide several good benefits, such as: adding religious information with a score of 3.5 (strongly agree), making them to like reading with a score of 3.5 (strongly agree), making them being happy to write with the score of 3.6 (strongly agree) and improving the learning achievement in madrasah aliyah with a score of 3.5 (strongly agree).

\subsection{Media Access}

The activity of media access, particularly the print media, it begins with reading activities. Students of MA YAJRI can read religious books, newspapers, magazines, religious books and Islamic novels during in the environment of Madrasah aliyah, but they are not allowed to access magazines, newspapers and novels while in the pesantren. While at the pesantren, they are merely allowed to access religious books, kitab kunings, and Al-Quran.

Newspapers can be accessed by students every day because pesantren subscribes to the Suara Merdeka newspaper and the Republika newspaper. They can read newspapers on the break times and sometimes newspapers are also displayed in Wall magazines. The officers who collect newspapers and put up on the wall paper are the administrators and members of the KSM. Then, based on interview data, some children stated that they liked reading newspapers, liked reading comics, and some liked news (interview with students, 05 October 2018)

Furthermore, to discover the level of access of KSM members to printed media which consists of religious books apart from PAI subject books, newspapers, magazines, kitab kunings, and Al-Quran can be seen in Figure 2. 


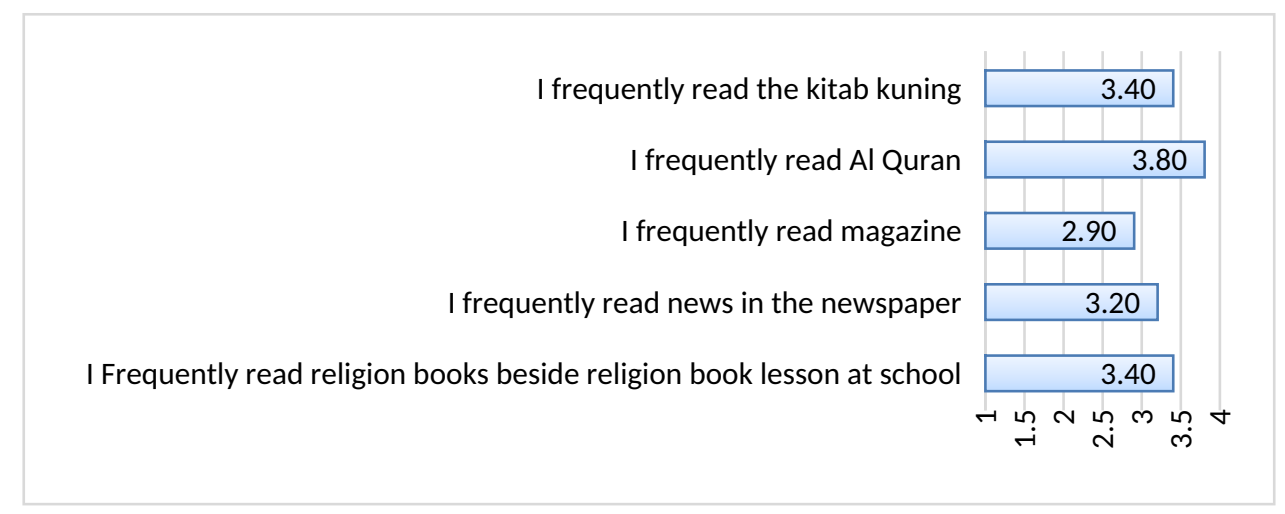

Fig 2. Access to print media

Access toward print media from the most frequently conducted is access to reading Alquran with a score of 3.8 (very often), reading religious books other than PAI subject books and reading kitab kunings with a score of 3.4 (very often) and reading Newspaper with the score of 3.2 (very often). The last order of media read by KSM members is reading magazines, namely 2.9 (often).

Access to reading Al-quran and the kitab kuning received high ratings due to KSM members had the task of memorizing Al-quran and thekitab kuning. Based on the results of field observations, students and students of the Sirajul Mukhlasin II pesantren at the same time during their spare time outside of school hours, they brought a small Alquran and kitab kuning, especially the Imrithi Book and the Fatkhul Qarib Book.

The obligation of MA YAJRI students to master the kitab kuning (islamic clasical manuscript) material is prioritized at MA YAJRI and it is part of the subjects taught in the madrasah aliyah. This policy was taken because according to the Head of the Supreme Court; Fiqh material was an essential material that must be mastered by students. The target of MA Yajri graduates was to master jurisprudence by learning through the book Fatkhul Qarib (Masykur, interview, 2 October 2018). The method applied when teaching and learning activities in class was carried out through students often asked to come in front of the class to read and explain the contents of the book (Masykur, interview, 11 October 2018).

The policy of the principal of the madrasah aliyah is taken seriously by applying the method of book teaching, specifically it is carried out by teachers of the kitab kuning subject. According to Habib Masykur, training with various methods had been carried out so that learning of the kitab kuning can be developed. In the learning process in the morning, students were only given theories and then the development in the form of book studies was carried out during extra activities. This was undertaken because not all curricula can be covered during learning in the morning, so there were developments in extra activities and diniyah schools (Masykur, 02 October 2018)

Furthermore, the head of the madrasah aliyah argued that the study of the Fathul Qarib Book was only taught 2 hours per week, indeed, this was one of the obstacles to be able to complete the student's target of completing the kitab kuning material such as the Fathkhul Qarib Book. Therefore, another strategy that implemented was by increasing nahwu learning. If the nahwu material had been achieved, the children can read the kitab kuning by themselves (Masykur, 02 October 2018) 
The principal of MA YAJRI also realized that it was impossible for all kitab kuning to be taught at the MA level so that the superior program of MA YAJRI related to master of religious knowledge was firstly nahwu science material, secondly was fiqh material and the third was hadith. Therefore, the target of memorizing the kitab kuning for students when graduating from third grade of MA was memorizing the Book of Imriti. While the fiqh material on mastery of the Book of Fathul Qarib and the material of hadith was prioritized for teaching the hadiths that were considered soheh and those that were associated with yaumiyah (hadith) (Masykur, 02 October 2018).

\subsection{Access toward electronic media}

Electronic media referred to here is television. Pesantren and madrasah aliyah had provided two parabolic antenna televisions, however students of MA YAJRI can merely access television on a limited basis. The regulation of the pesantren also limited what programs cannot be seen, namely Indian films, Western films and Korean films on television. They were only allowed to see Indonesian films. (interview with students, 5 October 2018). Thus, television access was lower than access to print media, so that from $30 \mathrm{KSM}$ members responded to electronic media access, namely watching religious lectures gained a score of 2.8 (often) and 2.2 (often).

\subsection{Access of religious information of the student community for writing (KSM) on teachers and parents}

Teachers or ustadz who teach religious knowledge through the kitab kuning tradition are important means in accessing religious information. Learning directly with a teacher or ustadz has more value than learning via the internet. The leader of Pesantren Sirajul Mukhlasin II stated that the real teachers were teachers who taught religious knowledge through books as religious teachings that were sent down by Allah SWT through His prophet. The teaching can open people's hearts to say sami'na waato'na to Allah SWT. It is different from learning via the internet which it only reads, thus, there is no comprehension deeply. Meanwhile, if learning with the teacher, just seeing its expression, the material can be understood easily. Like tasting food, what can feel was the expression of the person who felt it. Mimics cannot be felt on the internet (Minanurrahman, interview 2 October 2018)

The views of leader of Pesantren Srajul Mukhlasin II about the important role of teachers or ustadz as a place to learn to understand religious knowledge, it is in line with the opinion of KSM member students who often ask teachers about religious issues than their parents. The life of the students at the pesantren and at school causes them to be far from their parents. Likewise, in choosing figures to be asked about religious material, KSM members chose teachers (score 3.7 / very often) to ask questions more than their parents (score 3.3 / very often) who were far away at home.

\subsection{Understanding of religious media}

The students of MA YAJRI as well as KSM members stated that they were quite good on understanding the contents of the kitab kuning that had been taught both in madrasah aliyah and pesantren. The results of a survey of KSM member students pointed out that their understanding of religious books was in the very good category (score 3,2), while the understanding of the kitab kuning was also in very good category (score 3,4 ) 
The Imriti Book is one of the books taught at the pesantren of Siradjul Mukhlasin II. The students of KSM members actually agreed to memorize the Imriti Book with a score of 3.7 (strongly agree). Their ability to memorize the contents of the book with a score of 3,4 (very good). While the understanding of the book Imriti gained a score of 3.0 (good).

\subsection{The creation of knowledge}

The practice of media literacy with religious content of MA YAJRI students is produced by students who are members of KSM (Islamic Student Community for Writing) extra-curricular activities. KSM has successfully published the Sirajuna Bulletin and several articles that have been published through blog. The Student Community for Writing which can be accessed at http://www.yajri.or.id/ and blog: http://santrimenulis11.blogspot.com/. At the time of this research, it carried out on 29 articles that were published in the media, with material related to teaching and learning activities, news, freelance writing, and other thought writing. Apart from articles, there were also works in the form of poetry on the theme of love for the country, to celebrate Indonesia's independence day.

\section{$4 \quad$ Closing}

There are several conclusions can be taken, first, although there are restrictions on internet access for students of MA Yajri, however, it still provides opportunities to access the internet, one of which is through KSM activities. KSM members in accessing print media most often read the Al-quran with a score of 3.8 (very often), reading religious books other than PAI subject books and reading kitab kuning with a score of 3.4 (very often) and reading newspapers with a score of 3.2 (very often) ). The last order of media read by KSM members is reading magazines, namely 2.9 (often). Meanwhile, electronic internet media, namely television, is rarely accessed due to the time restrictions. Other sources of information and learning that accessed are information from teachers and parents.

Second, the comprehension of KSM member students towards religious books and book material is categorized into very well. Moreover, it is related to understanding on the book of imriti and rote.

Third, through the KSM forum, students can explore and train their potential to work and write. As evidence is the KSM product in the form of the "Sirajuna" bulletin which is published every month, and the publication of the Buku Ontologi Puisi (Poetry Ontology Book) and the Buku Ontologi Cerpen (Short Story Ontology Book). The written works of KSM members can also be accessed through online media, namely at http://www.yajri.or.id/ and blog: http://santrimenulis11.blogspot.com/.

\section{References}

[1] Dhofier, Zamakhsyari. 1982. Tradisi Pesantren. Jakarta: LP3ES.

[2] Arifina, A. S. 'Literasi Media sebagai Manajemen Konflik Keagamaan di Indonesia', Jurnal Komunikasi dan Kajian Media. 2017.

[3] Ja'far, A. 'Literasi Digital Pesantren: Perubahan Dan Kontestasi', Islamic Review: Jurnal Riset dan Kajian Keislaman, 8(1), pp. 17-35. doi: 10.35878/islamicreview.v8i1.156, 2019. 
[4] Ghazali, D. A. and Hermawan, A. H. 'Membangun Generasi Unggul Dengan Budaya Literasi melalui Kepemimpinan Pendidikan', Jurnal Isema: Islamic Educational Management, 2(1). doi: 10.15575/isema.v2i1.4992, 2019.

[5] Maskur, A. 'Penguatan Budaya Literasi di Pesantren', IQ (Ilmu Al-qur'an): Jurnal Pendidikan Islam ,2(01), pp. 1-16. doi: 10.37542/iq.v2i01.21, 2019.

[6] Muchibin, A. and Lathifah, A. 'Analisis kemampuan literasi informasi santri pesantren Futuhiyyah Mranggen Demak’, Jurnal Ilmu Perpustakaan, pp. 171-180, 2016.

[7] Muhith, A. 'Pembelajaran Literasi Membaca di Pesantren Sidogiri Kraton Pasuruan', Journal of Islamic Education Research, 1(01), pp. 34-50. doi: 10.35719/jier.v1i01.8, 2019.

[8] Fitriyah, L., Marlina, M. and Suryani, S. 'Pendidikan Literasi pada Pembelajaran Kitab Kuning di Pesantren Nurul Huda Sukaraja', Titian Ilmu: Jurnal Ilmiah Multi Sciences, 11(1), pp. 20-30. doi: 10.30599/jti.v11i1.351, 2019.

[9] Anwar, R. K., Komariah, N. and Rahman, M. T. 'Pengembangan Konsep Literasi Informasi Santri: Kajian di Pesantren Arafah Cililin Bandung Barat', Wawasan: Jurnal Ilmiah Agama dan Sosial Budaya, 2(1), pp. 131-142. doi: 10.15575/jw.v2i1.964, 2017.

[10] Hasanah, U. 'Pesantren Dan Transmisi Keilmuan Islam Melayu-Nusantara: Literasi, Teks, Kitab Dan Sanad Keilmuan', 'Anil Islam: Jurnal Kebudayaan Dan Ilmu Keislaman, 8(2), pp. 203-224, 2015.

[11] Mukaromah, Selli Annafi'atul \& Anwar, A. Z. 'Tingkat Literasi Zakat Kontemporer Pada Pesantren Salaf', The Journal for Aswaja Studies (J-ASNA), 1(1), pp. 47-58, 2019.

[12] Ihsan, M. 'Upaya Penguatan Pendidikan Agama Islam Berbasis Literasi Pesantren', LIBRARIA: Jurnal Perpustakaan, 6(1), p. 175. doi: 10.21043/libraria.v6i1.3832, 2018.

[13] Rifauddin, M., Ariyanti, N. N. and Pratama, B. A. 'Pembinaan Literasi di Pesantren Sebagai Bekal Santri Hidup Bermasyarakat', Info Bibliotheca: Jurnal Perpustakaan dan Ilmu Informasi, 1(2), pp. 99-112. doi: 10.24036/ib.v1i2.73.2020.

[14] Setiawan, A. R. 'Pendidikan Literasi Finansial Melalui Pembelajaran Fiqh Mu'āmalāt Berbasis Kitab Kuning', Nazhruna: Jurnal Pendidikan Islam, 3(1), pp. 138-159. doi: 10.31538/nzh.v3i1.522, 2020.

[15] Maknun, M. L. 'Potret Literasi Media MA Pesantren (Studi Kasus MA Maarif NU Kota Blitar)', ASNA: Jurnal Kependidikan Islam dan Keagamaan, 1(1), pp. 11-29. Available at: https://ejournal.maarifnujateng.or.id/index.php/asna/article/view/2/2 2019.

[16] Muslim, A. 'Curhat Di Balik Laci: Ekspresi Literasi Siswa Di Madrasah Aliyah Pesri Kendari', AlQalam, 25(1), p. 211. doi: 10.31969/alq.v25i1.728, 2019.

[17] Iswanto, A. 'Praktik Literasi Berbasis "Madrasah Riset”: Pelaksanaan Gerakan Literasi Di Mansa Yogyakarta', Al-Qalam, 24(2), p. 189. doi: 10.31969/alq.v24i2.468, 2018.

[18] Nur, M.) 'Literasi Digital Keagamaan Aktivis Organisasi Keagamaan di Madrasah Aliyah Negeri (MAN) di Kota Bandung', Jurnal SMART (Studi Masyarakat, Religi, dan Tradisi), 5(1), pp. 1-14. doi: 10.18784/smart.v5i1.745, 2019.

[19] Azani, M. Z. 'Literasi Digital Keagamaan Aktivis Organisasi Religious Digital Literacy Of Religious Organization Activism Pendahuluan', Tsaqofah, 05(01), pp. 1-27, 2019.

[20] Asma’ruf Priyatama, Karakter Melalui Gerakan Literasi Sekolah, prosisding seminari nasional, 2019.

[21] Citra Ningrum, C. H., Fajriyah, K. and Budiman, M. A.) 'Pembentukan Karakter Rasa Ingin Tahu Melalui Kegiatan Literasi', Indonesian Values and Character Education Journal, 2(2), p. 69. doi: 10.23887/ivcej.v2i2.19436, 2019.

[22] Setyaningsih, R. et al. () 'Penanaman etika komunikasi digital di pesantren melalui pemanfaatan elearning', Jurnal Kajian Komunikasi, 8(1), p. 128. doi: 10.24198/jkk.v8i1.24538, 2020.

[23] UNESCO. Global Media and Information Literacy (MIL) Assesement Framework: Readiness and Competencies. Paris: United Naions Educational Scientific and Cultural Organization (UNESCO), p.59, 2013

[24] UNESCO. Global Media and Information Literacy (MIL) Assesement Framework: Readiness and Competencies. Paris: United Naions Educational Scientific and Cultural Organization (UNESCO), pp. 129 $-130,2013$. 